\title{
OBITUARIES
}

\section{DR. JOHN WALKER}

The death of John Walker in November, 1964, removes from our midst one of the most respected and beloved figures in numismatics and Islamic studies. Walker was educated at the University of his native city, Glasgow, and went to Egypt in 1928 to serve in the Ministry of Education. On his return in 1931, he was appointed Assistant Keeper in the Department of Coins and Medals at the British Museum, to which he devoted the remainder of his life, becoming Deputy Keeper in 1949 and Keeper in 1952. Under his keepership, the new galleries were completed, making the British Museum coin room among the best appointed in the world. His courtesy and kindness were proverbial; a small boy who had dug up a grubby Roman denarius in the back garden would be accorded the same helpful treatment as a visiting academician, of whom there were many. His excellent qualities were also displayed in the management of the affairs of the Royal Numismatic Society, of which he was Secretary from 1948 onwards, and an editor of the Numismatic Chronicle since 1952. Walker was also Additional Lecturer in Arabic and Arab epigraphy at the School of Oriental and African Studies, London, from 1937 to 1947.

Walker's publications in the field of Oriental numismatics are distinguished by sound method, thoroughness and discrimination, together with the highest technical competence and mastery of the subject. He had begun with studies of Bible characters in the Koran and of folk medicine in Egypt. In 1936, the American Numismatic Society of New York brought out his monograph on the coinage of the second Saffarid dynasty of Sĩstān (ANS Notes and Monographs, No. 72). His greatest contribution to science, of course, resides in the two volumes of the new catalogue of Muhammadan coins in the British Museum. The first, dealing with Arab-Sassanian coinage, appeared in 1941, the second, covering the Arab-Byzantine and Umayyad series, in 1956. Walker did not confine himself to describing the specimens in the British national collection alone, but included examples from all over the world, rendering his work a veritable corpus. We must hope that his disciples will one day bring it to completion.

Walker was highly regarded internationally, being a Corresponding Member of the Swedish Academy and the Institut d'Égypte. In 1955, he received the Huntington Medal of the American Numismatic Society, and was awarded the Royal Numismatic Society's own medal the following year. He was elected to the British Academy in 1958 and appointed a C.B.E. in 1963. For many years, he was a valued member of the Royal Asiatic Society, and it was a matter of regret to the Council that his last illness prevented him from accepting an invitation to serve on that body.

It is hard even for one who knew him as well as I did to do justice to Walker's unique personality. He was the best type of Scot, with a perpetual twinkle in his eye, a complete lack of conceit or affectation, and a single-minded devotion to his colleagues and his profession. He never married, but was the best of companions. In Muslim numismatics, he was a true successor of Fraehn, Tiesenhausen and Lane Poole, and all who worked with him will forever cherish his memory.

DAVID M. LANG. 